\title{
PENGARUH KOMPETENSI PEGAWAI, KOMUNIKASI, LINGKUNGAN KERJA DAN ETOS KERJA TERHADAP PRODUKTIVITAS KERJA PEGAWAI DI KANTOR PELAYANAN PAJAK PRATAMA MEDAN POLONIA
}

\author{
Anthonius Yonathan Pardede \\ Universitas Islam Sumatera Utara \\ anthonius.pardede@gmail.com
}

\begin{abstract}
The formulation of the problem in this study are: Does Employee competency partially influence employee productivity at the Medan Polonia Tax Service Office, Does communication have a partial effect on employee work productivity, does the work environment partially affect employee work productivity?, Does the work ethic partial effect on employee work productivity? Does the employee competence, communication, work environment and work ethic jointly affect the employee work productivity in the Polonia Medan Primary Tax Office?, Research Objectives Are: To determine the effect of employee competency partially on employee work productivity, to determine the effect of employee communication partially on employee work productivity, to know the effect of work facilities partially on employee work productivity, to determine the effect of work ethic in a way rial on employee work productivity, to determine the effect of employee competence, communication, work environment and work ethic simultaneously on employee work productivity. Data analysis techniques used are descriptive analysis and deductive analysis. The results showed that there was a significant influence between employee competence on employee work productivity, because according to the results of the analysis of $t$ count $>t$-table (1.758> 1.67) at $n$ $=59$ with a significance level of 95\%. There is a significant effect between communication on employee work productivity, because according to the results of the analysis of $t$ count $>t$-table (3.183> 1.67) at $n=59$ with a significance level of 95\%. There is a significant influence between the work environment on employee work productivity, because according to the results of the analysis of $t$ count $>t$-table $(1.672>1.671)$ at $n=59$ with a significance level of $95 \%$. There is a significant influence between work ethic on employee work productivity, because according to the results of the analysis of tcount $>t$-table $(2,029>1.67)$ at $n=59$ with a significant level. $F$-count value $>F$ table (41,324> 2.54) together (multiple) there is a positive and significant effect on employee competence, communication, work environment and work ethic on employee work productivity. Thus the hypothesis proposed is accepted.
\end{abstract}

Keyworld: Employee competence, communication, work environment, work ethic and employee work productivity.

ABSTRAK : Rumusan masalah dalam penelitian ini adalah : Apakah kompetensi Pegawai
berpengaruh secara parsial terhadap Produktivitas kerja pegawai di Kantor Pelayanan Pajak
Pratama Medan Polonia, Apakah komunikasi berpengaruh secara parsial terhadap Produktivitas
kerja pergawai, Apakah lingkungan kerja secara parsial berpengaruh terhadap Produktivitas kerja
pegawai?, Apakah etos kerja berpengaruh secara parsial terhadap Produktivitas kerja pegawai?,
Apakah kompetensi pegawai, komunikasi, lingkungan kerja dan etos kerja secara bersama-sama
berpengaruh terhadap Produktivitas kerja pegawai di Kantor Pelayanan Pajak Pratama Medan
Polonia?, Tujuan Penelitiaan Adalah : Untuk mengetahui pengaruh kompetensi pegawai secara
parsial terhadap produktivitas kerja pegawai, untuk mengetahui pengaruh komunikasi pegawai
secara parsial terhadap produktivitas kerja pegawai, untuk mengetahui pengaruh fasilitas kerja
secara parsial terhadap produktivitas kerja pegawai, untuk mengetahui pengaruh etos kerja secara
parsial terhadap produktivitas kerja pegawai, untuk mengetahui pengaruh kompetensi pegawai,
komunikasi, lingkungan kerja dan etos kerja secara simultan terhadap produktivitas kerja
pegawai. Teknik analisis data yang digunakan adalah analisis deskriptif dan analisis deduktif.
Hasil penelitian diperoleh bahwa Ada pengaruh yang signifikan antara kompetrensi pegawai 
terhadap produktivitas kerja pegawai, karena menurut hasil analisis thitung > t-tabel $(1,758>$ 1,67) pada $n=59$ dengan taraf signifikansi 95\%. Ada pengaruh yang signifikan antara komunikasi terhadap produktivitas kerja pegawai, karena menurut hasil analisis thitung > t-tabel (3,183 > 1,67) pada $n=59$ dengan taraf signifikansi 95\%. Ada pengaruh yang signifikan antara lingkungan kerja terhadap produktivitas kerja pegawai, karena menurut hasil analisis thitung > t-tabel (1,672 $>1,671)$ pada $n=59$ dengan taraf signifikan 95\%. Ada pengaruh yang signifikan antara etos kerja terhadap produktivitas kerja pegawai, karena menurut hasil analisis thitung > t-tabel $(2,029$ $>1,67)$ pada $n=59$ dengan taraf signifikan.Nilai F-hitung $>F$ tabel $(41,324>2,54)$ secara bersama-sama (multiple) terdapat pengaruh positif dan signifikan kompetensi pegawai, komunikasi, lingkungan kerja dan etos kerja terhadap produktivitas kerja pegawai. Dengan demikian hipotesis yang diajukan diterima kebenarannya.

Keyworld : Kompetensi pegawai, komunikasi, lingkungan kerja, etos kerja dan produktivitas kerja pegawai.

\section{Pendahuluan}

Suatu organisasi didalam melaksanakan kegiatannya dan dalam mencapai tujuan selalu berkaitan erat dengan sumber daya yang ada terutama sumber daya manusia. Sumber daya manusia yang telah cukup tersedia belum cukup menjamin untuk mencapai tujuan organisasi apabila sumber daya manusia yang ada tidak memiliki keterampilan kerja yang baik dan produktivitas kerja yang tinggi. Produktivitas kerja pegawai dalam suatu organisasi masingmasing berbeda dan tergantung dari kemampuan serta keterampilan pegawai itu sendiri. Untuk mencapai produktivitas kerja pegawai tidak terlepas dari kemampuan pegawai. Upaya mencapai tujuan organisasi diperlukan sumber daya manusia yang memiliki kompetensi yang tinggi. Produktivitas kerja pegawai di

Kantor Pelayanan Pajak Pratama Medan Polonia masih rendah Hal ini disebabkan karena pengaruh beberapa faktor seperti kompetensi, komunikasi, lingkungan kerja dan etos kerja pegawai yang rendah. Produktivitas kerja yang tinggi diantaranya dipengaruhi kompetensi, Kompetensi pegawai yakni pengetahuan, keterampilan dan kemampuan atau kapabilitas yang dimiliki oleh seorang pegawai yang telah menjadi bagian dari dirinya sehingga mewarnai perilakunya dalam melaksanakan tugas yang diembannya. Selanjutnya kompetensi merupakan salah satu yang perlu diperhatikan. Kompetensi pegawai Kantor Pelayanan Pajak Pratama Medan Polonia masih rendah sehingga pegawai kurang terampil dalam melaksanakan tugas, kurang mampu melayani publik dengan baik Karena dengan kompetensi pegawai yang baik yaitu sikap dan kemampuan dari pegawai itu cukup baik untuk dapat melaksanakan tugas yang diberikan dan kesanggupan menghadapi masalah yang dihadapi dalam organisasi semakin baik, serta mampu untuk mencapai misi, nilai dan tujuan organisasi, kompetensi pegawai mempengaruhi produktivitas kerja organisasi. Kompetensi pegawai yang dimaksud adalah pengetahuan, keterampilan dan kemampuan atau kapabilitas yang dimiliki oleh seorang pegawai yang telah menjadi bagian dari dirinya sehingga mewarnai perilakunya dalam melaksanakan tugas yang diembannya.

Di dalam suatu organisasi informasi juga sangat penting baik bagi pegawai maupun bagi pimpinan organisasi. Bagi pegawai informasi diperoleh untuk kejelasan dan ketentuan yang menyangkut tugas yang dibebankan kepadanya. Bagi pegawai, informasi dibutuhkan menyangkut hasil kerja dan masalah-masalah yang dihadapi pegawai dan yang menyangkut diri pegawai itu sendiri. Informasi itu akan ada jika terjadi komunikasi yang luas. Komunikasi di Kantor Pelayanan Pajak Pratama Medan Polonia belum terlaksana dengan baik. Komunikasi antara pimpinan dan pegawai sangat penting begitu juga sesama pegawai. Dengan komunikasi yang baik antara sesama anggota organisasi akan dapat memperlancar segala kegiatan organisasi dan komunikasi yang lancar produktivitas kerja yang tinggi dapat tercapai.

Selanjutnya lingkungan kerja merupakan kondisi yang bersangkutan pada saat tempat kerja dibentuk perusahaan. Sejalan dengan pendirian perusahaan/instansi, manajemen selayaknya mempertimbangkan lingkungan kerja bagi pegawai. Perencanaan lingkungan kerja berarti menentukan susunan semua komponen fisik maupun non fisik yang mendukung aktivitas kerja pegawai. Disamping itu pegawai harus memiliki etos kerja yang tinggi karena etos kerja meliputi : efesiensi, 
tepat waktu, kejujuran, kesadaran untuk berubah, rasional dalam pengambilan keputusan, energik, kerjasama serta berorientasi ke masa depan, etos kerja akan mewarnai tingkah laku kita dalam bekerja dan akan tampil pada saat menjalankan peran masing-masing. Sewaktu menjalankan peran masing-masing, etos kerja seseorang akan dapat diketahui dengan berdasarkan ciri-ciri tertentu.

Kantor Pelayanan Pajak Pratama Medan Polonia memiliki sumber daya manusia yang berbeda sehingga produktivitas kerja juga berbeda. Sebagai instansi pemerintah harus dapat melayani publik dengan baik agar tujuan organisasi dapat tercapai sebagaimana yang diharapkan. Akan tetapi menurut prapenelitan dan pemantauan sementara, penulis memperoleh bahwa. Kompetensi pegawai masih rendah. Komunikasi pegawai juga masih kurang baik komunikasi sesama pegawai, dengan pimpinan maupun dengan masyarakat masih rendah sehingga produktivitas kerja juga belum maksimal. Begitu juga lingkungan kerja nampaknya belum mendukung kerja pegawai sehingga dalam menyelesaikan kerja hanya melepas tugas saja tidak ada upaya bagaimana agar hasil kerja mencapai produktivitas kerja yang tinggi. Etos kerja pegawai belum maksimal sehingga produktivitas kerja pegawai rendah.

Rendahnya kompetensi pegawai, kurang baiknya komunikasi, lingkungan kerja belum maksimal sehingga tidak mendukung terhadap kerja pegawai dan etos kerja pegawai masih rendah sehingga produktivitas kerja belum maksimal atau masih rendah, rendahnya beberapa faktor tersebut menyebabkan produktivitas kerja pegawai tidak seperti yang diharapkan.

Adapun tujuan penelitian ini adalah sebagai berikut :

a. Untuk mengetahui dan menganalisis pengaruh kompetensi pegawai terhadap produktivitas kerja pegawai di Kantor Pelayanan Pajak Pratama Medan Polonia.

b. Untuk mengetahui dan menganalisis pengaruh komunikasi terhadap produktivitas kerja pegawai di Kantor Pelayanan Pajak Pratama Medan Polonia. c. Untuk mengetahui dan menganalisis pengaruh lingkungan kerja terhadap produktivitas kerja pegawai di Kantor Pelayanan Pajak Pratama Medan Polonia.

d. Untuk mengetahui dan menganalisis pengaruh etos kerja terhadap produktivitas kerja pegawai di Kantor Pelayanan Pajak Pratama Medan Polonia.

e. Untuk mengetahui dan menganalisis pengaruh kompetensi pegawai, komunikasi, lingkungan kerja, dan etos kerja terhadap produktivitas kerja pegawai di Kantor Pelayanan Pajak Pratama Medan Polonia.

\section{Metode Penelitian}

\subsection{Populasi dan Sampel}

\section{Menurut Sugiyono}

(2010: 90) mengemukakan: Populasi adalah wilayah generalisasi yang terdiri atas objek/subjek yang mempunyai kualitas dan karakteritik tertentu yang ditetapkan oleh peneliti. Berdasarkan pengertian ini populasi bisa berupa semua individu yang mewakili pola kelakuan tertentu atau sebahagian dari kelompok itu. Populasi penelitian ini adalah semua pegawai di Kantor Pelayanan Pajak Pratama Medan Polonia berjumlah 119 orang.

Sampel penelitian ditetapkan berdasarkan ketentuan Arikunto, (2010:120) yaitu : Apabila populasi kurang dari 100 orang, lebih baik diambil semua sehingga penelitian merupakan penelitian populasi. Jika jumlah subjeknya lebih dari 100 orang, dapat diambil $10-15 \%$ atau 20 - 25\% atau lebih." Disebabkan populasi lebih 100 orang maka sampel penelitian ditetapkan sebesar 50\% (59 orang)

\subsection{Pengujian Validitas}

Uji validitas dilakukan terhadap isi dari suatu instrumen, tujuan dilakukannya pengujian ini adalah untuk mengukur ketetapan instrumen yang digunakan. Untuk pengujian validitas ini dilakukan dengan menggunakan koefisien korelasi Product Moment. Item kuesioner dikatakan valid apabila nilai $r_{\text {hitung }}>r_{\text {tabel }}$. Uji validitas pada penelitian ini dapat dilihat pada table berikut :

Tabel 1

Uji Validitas variable $\mathrm{X}_{1}$

\begin{tabular}{|c|c|c|c|c|}
\hline Pertanyaan & $\begin{array}{c}\text { Nilai Korelasi } \\
(\mathbf{r})\end{array}$ & $\begin{array}{c}\text { r-tabel } \\
(\mathbf{n = 5 9 )}\end{array}$ & Keterangan & Kesimpulan \\
\hline 1 & 0.597 & 0,252 & $\mathrm{r}_{\text {hitung }}>\mathrm{r}_{\text {tabel }}$ & Valid \\
\hline 2 & 0.426 & 0,252 & $\mathrm{r}_{\text {hitung }}>\mathrm{r}_{\text {tabel }}$ & Valid \\
\hline 3 & 0.603 & 0,252 & $\mathrm{r}_{\text {hitung }}>\mathrm{r}_{\text {tabel }}$ & Valid \\
\hline
\end{tabular}




\begin{tabular}{|c|c|c|c|c|}
\hline Pertanyaan & $\begin{array}{c}\text { Nilai Korelasi } \\
(\mathbf{r})\end{array}$ & $\begin{array}{c}\text { r-tabel } \\
(\mathbf{n = 5 9 )}\end{array}$ & Keterangan & Kesimpulan \\
\hline 4 & 0.643 & 0,252 & $\mathrm{r}_{\text {hitung }}>\mathrm{r}_{\text {tabel }}$ & Valid \\
\hline 5 & 0.659 & 0,252 & $\mathrm{r}_{\text {hitung }}>\mathrm{r}_{\text {tabel }}$ & Valid \\
\hline 6 & 0.734 & 0,252 & $\mathrm{r}_{\text {hitung }}>\mathrm{r}_{\text {tabel }}$ & Valid \\
\hline 7 & 0.604 & 0,252 & $\mathrm{r}_{\text {hitung }}>\mathrm{r}_{\text {tabel }}$ & Valid \\
\hline 8 & 0.513 & 0,252 & $\mathrm{r}_{\text {hitung }}>\mathrm{r}_{\text {tabel }}$ & Valid \\
\hline 9 & 0.652 & 0,252 & $\mathrm{r}_{\text {hitung }}>\mathrm{r}_{\text {tabel }}$ & Valid \\
\hline 10 & 0.585 & 0,252 & $\mathrm{r}_{\text {hitung }}>\mathrm{r}_{\text {tabel }}$ & Valid \\
\hline
\end{tabular}

Sumber : Hasil pengolahan Data, 2019

Tabel 2

Uji Validitas variable $\mathrm{X}_{2}$

\begin{tabular}{|c|c|c|c|c|}
\hline Pertanyaan & $\begin{array}{c}\text { Nilai Korelasi } \\
(\mathbf{r})\end{array}$ & $\begin{array}{c}\mathbf{r} \text {-tabel } \\
(\mathbf{n}=59)\end{array}$ & Keterangan & Kesimpulan \\
\hline 1 & 0.549 & 0,252 & $\mathrm{r}_{\text {hitung }}>\mathrm{r}_{\text {tabel }}$ & Valid \\
\hline 2 & 0.628 & 0,252 & $\mathrm{r}_{\text {hitung }}>\mathrm{r}_{\text {tabel }}$ & Valid \\
\hline 3 & 0.486 & 0,252 & $\mathrm{r}_{\text {hitung }}>\mathrm{r}_{\text {tabel }}$ & Valid \\
\hline 4 & 0.786 & 0,252 & $\mathrm{r}_{\text {hitung }}>\mathrm{r}_{\text {tabel }}$ & Valid \\
\hline 5 & 0.412 & 0,252 & $\mathrm{r}_{\text {hitung }}>\mathrm{r}_{\text {tabel }}$ & Valid \\
\hline 6 & 0.627 & 0,252 & $\mathrm{r}_{\text {hitung }}>\mathrm{r}_{\text {tabel }}$ & Valid \\
\hline 7 & 0.419 & 0,252 & $\mathrm{r}_{\text {hitung }}>\mathrm{r}_{\text {tabel }}$ & Valid \\
\hline 8 & 0.488 & 0,252 & $\mathrm{r}_{\text {hitung }}>\mathrm{r}_{\text {tabel }}$ & Valid \\
\hline 9 & 0.512 & 0,252 & $\mathrm{r}_{\text {hitung }}>\mathrm{r}_{\text {tabel }}$ & Valid \\
\hline 10 & 0.639 & 0,252 & $\mathrm{r}_{\text {hitung }}>\mathrm{r}_{\text {tabel }}$ & Valid \\
\hline
\end{tabular}

Sumber : Hasil pengolahan Data, 2019

Tabel 3

Uji Validitas variable $\mathrm{X}_{3}$

\begin{tabular}{|c|c|c|c|c|}
\hline Pertanyaan & $\begin{array}{c}\text { Nilai Korelasi } \\
(\mathbf{r})\end{array}$ & $\begin{array}{c}\mathbf{r} \text {-tabel } \\
(\mathbf{n = 5 9 )}\end{array}$ & Keterangan & Kesimpulan \\
\hline 1 & 0.546 & 0,252 & $\mathrm{r}_{\text {hitung }}>\mathrm{r}_{\text {tabel }}$ & Valid \\
\hline 2 & 0.611 & 0,252 & $\mathrm{r}_{\text {hitung }}>\mathrm{r}_{\text {tabel }}$ & Valid \\
\hline 3 & 0.612 & 0,252 & $\mathrm{r}_{\text {hitung }}>\mathrm{r}_{\text {tabel }}$ & Valid \\
\hline 4 & 0.758 & 0,252 & $\mathrm{r}_{\text {hitung }}>\mathrm{r}_{\text {tabel }}$ & Valid \\
\hline 5 & 0.716 & 0,252 & $\mathrm{r}_{\text {hitung }}>\mathrm{r}_{\text {tabel }}$ & Valid \\
\hline 6 & 0.685 & 0,252 & $\mathrm{r}_{\text {hitung }}>\mathrm{r}_{\text {tabel }}$ & Valid \\
\hline 7 & 0.479 & 0,252 & $\mathrm{r}_{\text {hitung }}>\mathrm{r}_{\text {tabel }}$ & Valid \\
\hline 8 & 0.415 & 0,252 & $\mathrm{r}_{\text {hitung }}>\mathrm{r}_{\text {tabel }}$ & Valid \\
\hline 9 & 0.420 & 0,252 & $\mathrm{r}_{\text {hitung }}>\mathrm{r}_{\text {tabel }}$ & Valid \\
\hline 10 & 0.448 & 0,252 & $\mathrm{r}_{\text {hitung }}>\mathrm{r}_{\text {tabel }}$ & Valid \\
\hline
\end{tabular}

Sumber : Hasil pengolahan Data, 2019

Tabel 4

Uji Validitas variable $\mathrm{X}_{4}$

\begin{tabular}{|c|c|c|c|c|}
\hline Pertanyaan & $\begin{array}{c}\text { Nilai Korelasi } \\
(\mathbf{r})\end{array}$ & $\begin{array}{c}\mathbf{r} \text {-tabel } \\
(\mathbf{n = 5 9 )}\end{array}$ & Keterangan & Kesimpulan \\
\hline 1 & 0.620 & 0,252 & $\mathrm{r}_{\text {hitung }}>\mathrm{r}_{\text {tabel }}$ & Valid \\
\hline 2 & 0.610 & 0,252 & $\mathrm{r}_{\text {hitung }}>\mathrm{r}_{\text {tabel }}$ & Valid \\
\hline 3 & 0.567 & 0,252 & $\mathrm{r}_{\text {hitung }}>\mathrm{r}_{\text {tabel }}$ & Valid \\
\hline 4 & 0.722 & 0,252 & $\mathrm{r}_{\text {hitung }}>\mathrm{r}_{\text {tabel }}$ & Valid \\
\hline 5 & 0.684 & 0,252 & $\mathrm{r}_{\text {hitung }}>\mathrm{r}_{\text {tabel }}$ & Valid \\
\hline 6 & 0.723 & 0,252 & $\mathrm{r}_{\text {hitung }}>\mathrm{r}_{\text {tabel }}$ & Valid \\
\hline 7 & 0.498 & 0,252 & $\mathrm{r}_{\text {hitung }}>\mathrm{r}_{\text {tabel }}$ & Valid \\
\hline 8 & 0.479 & 0,252 & $\mathrm{r}_{\text {hitung }}>\mathrm{r}_{\text {tabel }}$ & Valid \\
\hline 9 & 0.487 & 0,252 & $\mathrm{r}_{\text {hitung }}>\mathrm{r}_{\text {tabel }}$ & Valid \\
\hline 10 & 0.452 & 0,252 & $\mathrm{r}_{\text {hitung }}>\mathrm{r}_{\text {tabel }}$ & Valid \\
\hline
\end{tabular}

Sumber : Hasil pengolahan Data, 2019

Tabel 5

Uji Validitas variable Y

\begin{tabular}{|c|c|c|c|c|}
\hline Pertanyaan & $\begin{array}{c}\text { Nilai Korelasi } \\
(\mathbf{r})\end{array}$ & $\begin{array}{c}\mathbf{r} \text {-tabel } \\
(\mathbf{n}=59)\end{array}$ & Keterangan & Kesimpulan \\
\hline 1 & 0.588 & 0,252 & $\mathrm{r}_{\text {hitung }}>\mathrm{r}_{\text {tabel }}$ & Valid \\
\hline 2 & 0.487 & 0,252 & $\mathrm{r}_{\text {hitung }}>\mathrm{r}_{\text {tabel }}$ & Valid \\
\hline 3 & 0.619 & 0,252 & $\mathrm{r}_{\text {hitung }}>\mathrm{r}_{\text {tabel }}$ & Valid \\
\hline 4 & 0.547 & 0,252 & $\mathrm{r}_{\text {hitung }}>\mathrm{r}_{\text {tabel }}$ & Valid \\
\hline 5 & 0.575 & 0,252 & $\mathrm{r}_{\text {hitung }}>\mathrm{r}_{\text {tabel }}$ & Valid \\
\hline 6 & 0.532 & 0,252 & $\mathrm{r}_{\text {hitung }}>\mathrm{r}_{\text {tabel }}$ & Valid \\
\hline 7 & 0.529 & 0,252 & $\mathrm{r}_{\text {hitung }}>\mathrm{r}_{\text {tabel }}$ & Valid \\
\hline 8 & 0.538 & 0,252 & $\mathrm{r}_{\text {hitung }}>\mathrm{r}_{\text {tabel }}$ & Valid \\
\hline 9 & 0.401 & 0,252 & $\mathrm{r}_{\text {hitung }}>\mathrm{r}_{\text {tabel }}$ & Valid \\
\hline 10 & 0.642 & 0,252 & $\mathrm{r}_{\text {hitung }}>\mathrm{r}_{\text {tabel }}$ & Valid \\
\hline
\end{tabular}

Sumber : Hasil pengolahan Data, 2019 
Pada Tabel diatas dapat diperoleh nilai korelasi semua variabel lebih besar dari 0,252. Hal ini menunjukkan bahwa semua item pertanyaan masing-masing variabel adalah valid.

\subsection{Analisis Regresi Linear Berganda}

Analisis regresi digunakan untuk menganalisis data hasil penelitian dengan maksud untuk memperoleh gambaran hubungan fungsional antara variabel bebas dengan variabel terikat hal ini dengan menggunakan analisis regresi linier berganda.

Tabel 6

Koefisien Regresi

\begin{tabular}{|c|c|c|c|c|c|c|}
\hline & \multirow[t]{2}{*}{ Model } & \multicolumn{2}{|c|}{$\begin{array}{l}\text { Unstandardized } \\
\text { Coefficients }\end{array}$} & \multirow{2}{*}{$\begin{array}{c}\text { Standardized } \\
\text { Coefficients } \\
\text { Beta }\end{array}$} & \multirow[t]{2}{*}{ t. } & \multirow[t]{2}{*}{ Sig. } \\
\hline & & B & Std. Error & & & \\
\hline \multirow{5}{*}{1} & (Constant) & 13,022 & 2,068 & & 6,296 & 000 \\
\hline & Kompetensi &, 147 & 084 & 174 & 2,758 & 034 \\
\hline & Komunikasi & ,269 & 085 & ,313 & 3,183 & ,002 \\
\hline & Lingkungan kerja & ,149 & 089 & 227 & 2,673 & 014 \\
\hline & Etos kerja & 192 & 095 & 269 & 3,029 & 027 \\
\hline
\end{tabular}

Sumber : Hasil Pengolahan Data, 2019

Berdasarkan Tabel 6, diperoleh koefisien regresi variabel Kompetensi 0,147, Komunikasi $=0,269$, Lingkungan Kerjai 0,149, etos kerja 0,192 dengan konstanta 13,022, maka dapat dituliskan persamaan regresi sebagai berikut.

$$
Y=13,022+0,147 X_{1}+0,269 X_{2}+0,149 X_{3}+
$$

Persamaan di atas menunjukkan konstanta bernilai positip dan nilai koefisien regresi juga positip. Hal ini memberi gambaran bahwa perubahan rata-rata variabel produktivitas Kerja (Y) tergantung dari perubahan variabel Kompetensi Pegawai $\left(\mathrm{X}_{1}\right)$, Komunikasi $\left(\mathrm{X}_{2}\right)$.

\section{Tabel 7}

Uji F (Uji Simultan)

ANOVA

Lingkungan Kerja $\left(\mathrm{x}_{3}\right)$ dan etos kerja $\left(\mathrm{x}_{4}\right)$. Artinya apabila Kompetensi Pegawai, Komunikasi, Lingkungan Kerja dan etos kerja ditingkatkan akan diikuti perubahan/peningkatan produktivitas kerja pegawai. Perubahan ini merupakan peningkatan apabila bertanda positip dan penurunan atau pengurangan jika bertanda negatif. Hal ini menunjukkan bahwa ada pengaruh Kompetensi, Komunikasi, Lingkungan Kerjai dan etos kerja terhadap produktivitas kerja

\subsection{Uji Signifikan Simultan (Uji F)}

\begin{tabular}{|rl|r|r|r|r|r|}
\hline \multicolumn{2}{|r|}{ Model } & \multicolumn{1}{c|}{$\begin{array}{c}\text { Sum of } \\
\text { Squares }\end{array}$} & df & \multicolumn{1}{c|}{$\begin{array}{l}\text { Mean } \\
\text { Square }\end{array}$} & F & Sig. \\
\hline \multirow{2}{*}{1} & Regression & 116,641 & 4 & 29,160 & 41,324 &, $000^{\mathrm{b}}$ \\
& Residual & 38,105 & 54 &, 706 & & \\
& Total & 154,746 & 58 & & & \\
\hline
\end{tabular}

a. Dependent Variable: produktivitas pegawai

b. Predictors: (Constant), Etos kerja, Komunikasi, Kompetensi, Lingkungan kerja

Berdasarkan tabel di atas diketahui bahwa nilai F-hitung sebesar 41,324 sedangkan nilai Ftabel dengan $\mathrm{dk}$ pembilang $4 \mathrm{dan} \mathrm{dk}$ penyebut 59 adalah sebesar 2,54 dimana F-hitung > F tabel $(41,324>2,54)$ maka dapat disebutkan bahwa secara bersama-sama (simultan) terdapat pengaruh positif dan signifikan Kompetensi,
Komunikasi,Lingkungan Kerja dan etos kerja terhadap produktivitas kerja pegawai.

\subsection{Uji Signifikan Parsial (t)}

Untuk mengetahui pengaruh variabel bebas secara parsial terhadap variabel terikat digunakan uji t, dimana dengan ketentuan : 
a. $\mathrm{t}$ - hitung $\leq \mathrm{t}$ - tabel (tidak ada pengaruh variabel bebas secara tersendiri terhadap variabel terikat) b. t- hitung > t- tabel (ada pengaruh variabel bebas secara tersendiri terhadap variabel terikat)

c. derajat kebebasan $(\mathrm{dk})=\mathrm{n}-4$ dan Tingkat kepercayaan $\alpha=0,05$.

Tabel 8

Koefisien Regresi

\begin{tabular}{|c|c|c|c|c|c|c|}
\hline & \multirow{2}{*}{ Model } & \multicolumn{2}{|c|}{$\begin{array}{c}\text { Unstandardized } \\
\text { Coefficients }\end{array}$} & \multirow{2}{*}{$\begin{array}{c}\text { Standardized } \\
\text { Coefficients } \\
\text { Beta }\end{array}$} & \multirow[t]{2}{*}{ t. } & \multirow{2}{*}{ Sig. } \\
\hline & & $\mathrm{B}$ & Std. Error & & & \\
\hline \multirow{5}{*}{1} & (Constant) & 13,022 & 2,068 & & 6,296 & 000 \\
\hline & Kompetensi &, 147 & ,084 &, 174 & 2,758 & ,034 \\
\hline & Komunikasi & ,269 & 085 & ,313 & 3,183 & ,002 \\
\hline & Lingkungan kerja &, 149 & ,089 & ,227 & 2,673 & ,014 \\
\hline & Etos kerja & 192 & ,095 & 269 & 3,029 & 027 \\
\hline
\end{tabular}

Sumber : Hasil Pengolahan Data, 2019

Berdasarkan tabel 8, di atas diperoleh :

1. Nilai $t_{\text {hitung }}$ kompetensi $=2,758$, sedangkan $\mathrm{t}-$ tabel dengan dk 59 sebesar 2.004 maka thitung > t-tabel dengan demikian secara parsial ada pengaruh yang signifikan antara Kompetensi Pegawai terhadap produktivitas pegawai.

2. Nilai $t_{\text {hitung }}$ komunikasi $=3,183$, sedangkan $t-$ tabel dengan dk 59 sebesar 2.004 maka $t$ hitung > t tabel dengan demikian secara parsial ada pengaruh yang signifikan antara komunikas terhadap produktivitas pegawai.

Tabel 9

3. Nilai $t_{\text {hitung }}$ lingkungan kerja $=2,673$, sedangkan t-tabel dengan $\mathrm{dk} 59$ sebesar 2.004 maka $\mathrm{t}$ hitung $>\mathrm{t}$ tabel dengan demikian secara parsial ada pengaruh yang signifikan antara lingkungan kerja terhadap produktivitas pegawai.

4. Nilai $t_{\text {hitung }}$ etos kerja $=3,029$, sedangkan $t$ tabel dengan dk 59 sebesar 2.004 maka $t$ hitung > t tabel dengan demikian secara parsial ada pengaruh yang signifikan antara etos kerja terhadap produktivitas pegawai.

\subsection{Uji Determinasi (R Square)}

Koefisien Determinasi

Model Summary

\begin{tabular}{|l|r|r|r|r|}
\hline Model & R & R Square & Adjusted R Square & Std. Error of the Estimate \\
\hline 1 &, $868^{\mathrm{a}}$ &, 754 &, 736 &, 84003 \\
\hline
\end{tabular}

Sumber; Pengolahan data, 2019

Berdasarkan table 9, diperoleh $\mathrm{R}^{2}=0,754$ maka $\mathrm{D}=0,754 \times 100 \%$ sehingga $\mathrm{D}=75,4 \%$. Akan tetapi dalam regresi multiple lebih baik digunakan nilai adjusted $\mathrm{R}$ Square $=0,736$ Dengan demikian pengaruh Kompetensi, Komunikasi, Lingkungan Kerja dan etos kerja terhadap produktivitas Kerja sebesar $73,6 \%$. sedangkan $26,4 \%$ lagi yang mempengaruhi produktivitas Kerja ditentukan faktor lain yang tidak diteliti dalam penelitian ini.

\section{Kesimpulan}

Berdasarkan pada analisis dan evaluasi data di atas, maka kesimpulan dari penelitian ini adalah :
1. Variabel kompetensi pegawai berpengaruh positif dan signifikan terhadap produktivitas kerja pegawai di Kantor Pelayanan Pajak Pratama Medan Polonia dengan nilai $t$ hitung > t table $(2,758>2.004)$

2. Variabel komunikasi berpengaruh positif dan signifikan terhadap produktivitas kerja pegawai di Kantor Pelayanan Pajak Pratama Medan Polonia dengan nilai $\mathrm{t}$ hitung $>\mathrm{t}$ table $(3,183>2.004)$

3. Variabel lingkungan kerja berpengaruh positif dan signifikan terhadap produktivitas kerja pegawai di Kantor Pelayanan Pajak Pratama Medan Polonia dengan nilai $t$ hitung > t table $(2,673>2.004)$ 
4. Variabel etos kerja berpengaruh positif dan signifikan terhadap produktivitas kerja pegawai di Kantor Pelayanan Pajak Pratama Medan Polonia dengan nilai $\mathrm{t}$ hitung $>\mathrm{t}$ table $(3,029>2.004)$

5. Variabel kompetensi pegawai, komunikasi, lingkungan kerja dan etos kerja secara bersama sama berpengaruh positif dan signifikan terhadap produktivitas kerja pegawai di Kantor Pelayanan Pajak Pratama Medan Polonia dengan Nilai F-hitung > F tabel $(41,324>2,54)$.

\section{DAFTAR PUSTAKA}

Alwi Syafaruddin, (2011), Manajemen Sumber Daya Manusia, Yogyakarta.: BPFE, UGM

Anoraga, Pandji. (2009). Manajemen Bisnis. Jakarta. Rineka Cipta,

Arikunto, Suharsimi, (2010. Prosedur Penelitian Suatu Pendekatan Praktek, Jakarta, Rineka Cipta.

As'ad, (2011), Penentuan Sepuluh Menit Penilaian Kinerja, Yogyakarta : Andi

Bertens, K. (2011). Etika., Jakarta.Gramedia

Effendy, Onong, Uchjana, (2009), Dinamika Komunikasi, Bandung, PT. Remaja Rosda karya,

Luthans, Fred. (2009). Perilaku Organisasi. Yogyakarta, Andi,

Mar,at, (2013), Pimpinan dan Kepemimpinan, Jakarta : Ghalia Indonesia

Mitrani, Alain, (2009), Manajemen Sumber Daya Manusia Berdasarkan Kompetensi, Jakarta, Pustaka Utama Grafiti

Moenir, A. S, (2009) : Pendekatan Manusia dan Organisasi terhadap Pembinaan Kepegawaian, Jakarta.Gunung Agung

Moenir, A. S, (2014) :Pendekatan Manusia dan Organisasi Terhadap Pembinaan Kepegawaian, Jakarta.Gunung Agung

Nitisemito Alex S,.(2011). Manajemen Personalia, Jakarta, Ghalia Indonesia

Poerwono, Hadi, (2012) : Tata Personalia, Bandung, Djambatan,

Sanjaya, Wina, (2010), Kompetensi, EdisiPertama, Cetakan I, Jakarta, FajarInterpratama Offset.

Sastrosapoetra, RA. Santoso, (2012), Manusia dan Organisasi, Jakarta :Gunung Agung

Siahaan, S.M. (2010), Komunikasi Pemahaman dan Penerapannya, Jakarta, BPK GunungMulia,

Siagian Sondang P, (2009), Manajemen Sumber Daya Manusia, Cetakan I Jakarta : Penerbit Bumi Aksara.
Sinamo, Jansen. (2013). Delapan Etos Kerja Profesional: Navigator Anda Menuju Sukses. Bogor. Grafika Mardi Yuana.

Soekirno, Sadono, (2013). Pengantar Ekonomi Makro, Jakarta: LPFE-UI

Sudjana, 2011), (Metoda Statistika), Tarsito, Bandung.

Sugiyono, (2010 :Metode Penelitian Administrasi, Alfabeta, Bandung

Supranto(2009), Dasar-Dasar Organisasi dan Manajemen, Jakarta Gunung Agung.

Suryadi Prawirosenono, (2014). Filosofi Baru Tentang Manajemen Mutu Terpadu, Jakarta, Bumi Aksara.

Suryabrata, (2011). Metodologi Penelitian,Jakarta :Rajawali

Suseno, K, 2012, Manajemen Sumber Daya Manusia di Era Globalisasi, Jakarta : Bumi Aksara

Semiawan, (2009), KebijakanPublik, Jakarta, PT. Elex Media Komputindo,

Tasmara, (2012), Pengantar Studi Penelitian Kebijakan, Jakarta Bumi Aksara.

Winardi, (2012), Manajemen Perilaku Organisasi, Jakarta, Kencana

Wijaya Tony, (2011), Cepar Menguasai SPSS Untuk Olah \& Interpretasi Data Penelitian, Yogyakarta. Cahaya Atma

Wetik, J. L, (2012). Penelitian dan Produktivitas, Jakarta, Erlangga 